\title{
Doubly crowned: The Public and Private Image of Two Fourteenth-Century Hungarian Queens
}

\author{
Christopher Mielke \\ Al-Quds Bard College (College for Arts and Sciences), \\ Jerusalem, thechrismielke@gmail.com
}

\section{Abstract}

Art as propaganda is traditionally thought to be used as a tool of monarchs in cementing their role. In addition to coins with the king's face and seals featuring the king in majesty, the king's face could also appear on public art such as statues, stained glass, and even frescoes. This essay seeks to understand four pieces of stonework visible to the medieval public which would have featured two fourteenth-century queens of Hungary: Elizabeth of Poland (d. 1380), wife of Charles I Robert, and Elizabeth of Bosnia (d. 1387), wife of Louis I 'the Great' ( $r$. 1342-1382).

Keywords: Medieval Hungary; queenship; Elizabeth of Poland; Elizabeth of Bosnia; Angevin Dynasty; public representation; images; propaganda; statues. 


\title{
Doubly crowned: The Public and Private Image of Two Fourteenth-Century Hungarian Queens
}

\author{
Christopher Mielke \\ Al-Quds Bard College (College for Arts and Sciences), \\ Jerusalem
}

\section{Introduction}

Whether on stained glass, statues, or wall paintings, it was understood that the image of a medieval king in a public place was part of a much larger programme of dynastic propaganda, legitimacy, and promotion of the king's self-image. ${ }^{1}$ However, while the king's face appeared on many public monuments, only a few scholars have examined the question of the queen's appearance on public art such as stained glass or statue columns. ${ }^{2}$ Part of this could very well be due to the peculiar nature of the queen's power and self-representation. Queens were both privileged by their access not only to the court but also by their stream of revenues; that being said, they were also restricted in action by not only ideas of their ideal behaviour, but also even by the roles expected of them. Complicating this issue, most of the historical material available on the lives of queens is only found in public, in formal acts related to their official duties; these tend to only be found in charters, statues, donations, and documents associated with their gifts and

${ }^{1}$ John Steane, The Archaeology of the Medieval English Monarchy (London \& New York: Routledge, 1999), 14-22.

2 See: Kathleen Nolan, Queens in Stone and Silver (New York: Palgrave Macmillan, 2009); Meredith Parsons Lillich, The Queen of Sicily and Gothic Stained Glass in Mussy and Tonnerre (Philadelphia: American Philosophical Society, 1998). 
patronage. ${ }^{3}$ In the case of medieval Hungary, the surface related to the public image of the queen is just beginning to be scratched. One of the few articles to broach this topic in English has pointed to trends in the historical literature to discuss queens of Hungary within the context of their roles not only as suspicious women who have the king's ear, but also as foreigners who were also harbingers of greedy foreigners eager to rule the realm. ${ }^{4}$

\section{Family tree of late fourteenth century Hungarian queens}

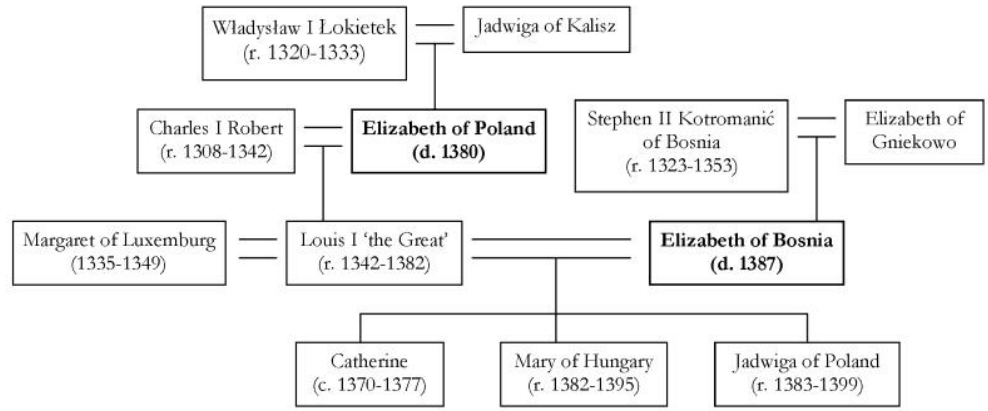

Sources: Dercsényi, Dezsô, ed. The Hungarian Illuminated Chronicle. Budapest: Corvina Kiadó, 1969 Dlugosz, Jan and Maurice Michael ed. The Annals of Jan Dlugos\%. Chichester: IM Publications, 1997.

Fig. 1. Family tree showing relations of Elizabeth of Poland with Elizabeth of Bosnia

With all this in mind, this essay seeks to understand the public images of two medieval Hungarian queens (Elizabeth of Poland, d. 1380, and Elizabeth of Bosnia, d. 1387, Figure 1) who appear on a total of four stone carvings. The principle questions of this essay concern how the ambiguous nature of the queen is evident in public images of the queen. Which of these images are made with the queen's own agency, and how does that impact their form and appearance? Do

\footnotetext{
3 Theresa Earenfight, Queenship in Medieval Europe (New York: Palgrave Macmillan, 2013), 25-26.

4 János M. Bak, "Queens as Scapegoats in Medieval Hungary" in Queens and queenship in medieval Europe, ed. Anne J. Duggan (Woodbridge: Boydell Press, 2002), 223-233.
} 
events in the queen's life course (i.e. marriage, widowhood, childbirth, etc.) impact the form of the image? How are identifying markers like clothing, physiognomy, and heraldry used to indicate that this is indeed the particular queen? In short, what can these statues tell us about the nature of queenship for these two very different women?

\section{Elizabeth of Poland (d. 1380) and Elizabeth of Bosnia (d. 1387)}

Elizabeth of Poland (d. 1380) was the daughter of Wladyslaw I Lokietek (r. 1320-1333) and Jadwiga of Kalisz. In 1320, Elizabeth married Charles I Robert of Hungary (r. 1308-1342), having five sons and possibly two daughters together. ${ }^{5}$ After her husband's death in 1342, the queen became wealthy and influential. She began major construction works at her castle in Óbuda, ${ }^{6}$ she was a significant patron of monastic orders, particularly the Franciscans, ${ }^{7}$ and she was also a

5 Jan Długosz, Maurice Michael ed., The Annals of Jan Dtugosz (Chichester: IM Publications, 1997), 269; Gyula Kristó, "Károly Róbert családja" [The Family of Charles Robert] Aetas 20:4 (2005): 15, 25-26; Klára Gárdonyi-Csapodi, "Description and Interpretation of the Illustrations in the Illuminated Chronicle" in The Hungarian Illuminated Chronicle: Chronica de Gestis Hungarorum, ed. Dezső Dercsényi (Budapest: Corvina Press, 1969), 83.

6 Julianna Altmann, "Neueste Forschungen der Burg der Königin in Óbuda" Acta Archaeologica Academiae Scientiarum Hungariae 34 (1982): 222-231; Julianna Altman, "Óbuda," in Medium Regni: Medieval Hungarian Royal Seats, ed. Julianna Atlmann et al. (Budapest: Nap Kiadó, 1999), 89-109; Krisztina Havasi, "A király új palotája. Megjegyzések a kora 13. századi óbudai rezidencia művészettörténeti helyéhez" [A new palace for the king. remarks on the place in art history of the early $13^{\text {th }}$-century royal residence at Óbuda] in In medio regni Hungariae. Régészeti, Múvészettörténeti és történeti kutatások 'az ország közepén': Archaeological, Art Historical, and Historical Researches in the Middle of the Kingdom, ed. Elek Benkő and Krisztina Orosz (Budapest: Magyar 'Tudományos Akadémia, 2015), 405-469.

${ }^{7}$ For an overview of her patronage, see: Eva Sniezynska-Stolot, "Queen Elizabeth as Patron of Architecture" Acta Historiae Artium 20 (1974): 13-19; Beatrix Romhányi, Kolostorok és társaskáptalanok a középkori Magyarországon: katalógus [Monasteries and collegiate chapters in medieval Hungary: a catalog] (Pytheas, 2000), 9, 12, 16, 55, 60-61. For specific studies on her construction of the Obuda Poor Clares cloister (her burial place), see: Herta Bertalan, "Óbudai Klarissza Kolostor" [The Obuda Poor Clares Cloister] Budapest Régiségei 27 (1976): 269-278; Herta Bertalan, "Das Klarissenkloster von Óbuda aus dem 14. Jahrhundert" Acta Archaeologica Academiae Scientiarum Hungaricae 34 (1982): 151-176; Brian McEntee, "The Burial Site Selection of a Hungarian Queen: Elizabeth, Queen of Hungary (1320-1380), and the Óbuda Clares' Church," Annual of 
rich donor of reliquaries and books to the Church, as evidenced by the donations in her will. ${ }^{8}$ She is also known for her two significant pilgrimages; in 1343, she made a journey to Italy, visiting Rome, Naples, and Bari to support her son Andrew's claim to the title of King of Naples; ${ }^{9}$ while in 1357, she visited holy sites in Prague, Marburg, Cologne, and Aachen, a journey she made with Charles IV of Bohemia and Anna of Schweidnitz, a granddaughter of her husband Charles I Robert. ${ }^{10}$

Though Elizabeth of Poland was in many ways a conventional queen, there are several controversial aspects of her life. In 1330, while the royal family was in Visegrád, a nobleman named Felician Záh drew his sword and attempted to kill Charles I Robert and Elizabeth of Poland. According to the Hungarian Illuminated Chronicle, he wounded the king in the right hand and succeeded in severing four fingers of the queen's right hand. In the words of the chronicler,

...he severed four fingers which in her almsgiving she was wont to extend in pity to the poor, the wretched and the downcast. With these fingers she had been wont to sew

Medieval Studies at the CEU 12 (2006), 69-82; Brian McEntee, "Queen Elizabeth of Hungary (1320-1380) and Óbuda: Patronage, Personality and Place," in La diplomatie des États Angevins au XIIIe et XIVe siècles, ed. Zoltán Kordé and István Petrovics (Rome and Szeged, 2010), 209-218.

8 Ernő Marosi, “A 14. századi Magyarország udvari művészettörténetírásban” [Art history of the Hungarian court in the fourteenth century] in Múvészet I. Lajos király korában 1342-1382. Katalógus, Ernő Marosi et al. (Budapest: MTA Művészettörténeti Kutató Csoport, 1982), 73-75, n 32; László Szende, "Mitherrscherin oder einfach Königinmutter Elisabeth von Lokietek in Ungarn (1320-1380)” Majestas 13 (2005): 4763.

9 László Szende, "Piast Erzsébet és udvara (1320-1380)" [Elizabeth Piast and her court (1320-1380)] (PhD diss.: ELTE, 2007), 133-137; Dragoş Gheorge Nastasoiu, "Patterns of Devotion and Traces of Art during the Diplomatic Journey of Queen Elizabeth Piast to Italy in 1343-1344" in Convivium: Exchanges and Interactions in the Arts of Medieval Europe, Byzantium, and the Mediterranean, ed. Michele Bacci and Ivan Foletti (Turnhout: Brepols, 2015), 102-103; Marianne Sághy, "Dévotions diplomatiques: Le pèlerinage de la reine-mère Élisabeth Piast à Rome" in La Diplomatie des États Angevins aux XIIIe et XIVe siècle, ed. Zoltán Kordé and István Petrovics (Rome and Szeged: 2010), 219-224.

10 On this journey, Elizabeth also visited cities at Pilsen, Sulzbach, Heilbronn, Mergentheim, and Frankfurt. Szende, "Piast Erzsébet és udvara (1320-1380)", 139; Dragoş Gheorge Nastasoiu, "Patterns of Devotion and Traces of Art. The Pilgrimage of Queen Elizabeth Piast to Marburg, Cologne, and Aachen in 1357" Umĕní LXIV (2016): 31-33. 
varied embroideries for innumerable churches, and she was tireless in sending ornamental robes of precious purple for the priests and chalices for the altars. ${ }^{11}$

After Záh attacked the princes, he was cut down by a cup-bearer to the queen and his whole family was executed in the aftermath. While in and of itself, this attack on the royal family is not controversial, later chroniclers (for instance, Jan Dlugosz) place the blame for the attack on the queen, weaving a tall tale of the queen securing Záh's daughter for her brother to rape being the reason for his violent outburst. ${ }^{12}$ There is also the matter of Elizabeth's time as Regent of Poland from 1370 to 1375 . As sister of the recently-deceased Casimir III of Poland (r. 1333-1370), the queen seemed a natural fit for regent when her son inherited the Polish throne. However, tensions erupted during her regency (which Długosz naturally blames on the queen), culminating in the queen's hasty retreat and resignation of the post after the Poles go on a massacre targeting Hungarians and killing up to 160 of them in $1375 .{ }^{13} \mathrm{It}$ is also worth mentioning a keystone from a building at the Market Square in the city of Kraków. It depicts a younger woman with a long nose, wide mouth, and an elaborate headdress without a crown. The vaulting and sculpture have been dated either to 1386 or 1375 . Though the woman wears no crown, she has been identified as Elizabeth of Poland, though it seems more probable that it represents her granddaughter, Jadwiga of Poland (r. 1384-1399), and as such will not be discussed here. ${ }^{14}$

Elizabeth of Bosnia faced many problems as a queen consort, dowager, and regent. The daughter of Stephen II (r. 1322-1353), Ban of Bosnia and Elizabeth of Gniewkowo (a cousin of Elizabeth of Poland), Elizabeth of Bosnia married Louis I in Buda in June 1353. ${ }^{15}$ In spite of

11 Dezső Dercsényi, ed. The Hungarian Illuminated Chronicle: Chronica de Gestis Hungarorum (Budapest: Corvina Press, 1969), 146.

12 Ibid., 146-147; Długosz, The Annals of Jan Dlugosz, 277-278; Bak, "Queens as Scapegoats in Medieval Hungary," 229.

13 Długosz, The Annals of Jan Dlugosz, 326-331.

14 Éva Sniezynska-Stolot, "Die Ikonographie der Königin Elisabeth" Acta Historiae Artium 17 (1971): 27.

15 John Fine, The Late Medieval Balkans (Ann Arbor: University of Michigan Press, 1994), 369; Długosz, The Annals of Jan Dlugosz, 303; Dženan Dautović, "Bosansko-ugarski odnosi kroz prizmu braka Ludovika I Velikog i Elizabete kćerke Stjepana II Kotromanića" [Relations between Bosnia and Hungary through the prism of the 
her status as the queen consort, the younger Elizabeth was mostly kept in the shadows; it is not until 1370 (seventeen years after her marriage) that there is a first solid evidence for her issuing a charter of her own using her own seal. ${ }^{16}$ This can possibly be tied to the troubles the queen had conceiving: it was not until 1370 that she had her oldest daughter, Catherine (d. 1378), followed by the birth of Maria in 1371 (Queen Regnant of Hungary from 1382-1395), and Hedwig in 1373 (Queen Regnant of Poland from 1384-1399). $\cdot{ }^{17}$ It was sometime after the birth of her eldest daughter that Elizabeth of Bosnia would have written a book of instruction for her daughters, one of the first of its kind in the medieval world. The manuscript does not survive, but it is mentioned in Georffrey de la Tour-Landry's Book of the Knight of the Tower, a manual of behaviour he had written for his daughters ca. 1371-1372. ${ }^{18}$ As negotiations had been opened for a marriage alliance between Louis (d. 1407), son of Charles V of France, and Catherine, the eldest daughter between Louis of Hungary and Elizabeth of Bosnia, it has been proposed that a copy of the queen's book had been sent to the French court in 1374 as part of the marriage negotiations which ended with Catherine's death in 1378. ${ }^{19}$ Aside from this book and her gifts to the church of St. Simeon in Zadar, the bulk of Elizabeth of Bosnia's activities come from her turbulent time as Queen Regent, from the death of her husband in 1382 until her imprisonment and eventual

marriage between Louis the Great and Elizabeth, the Daughter of Stjepan II Kotromanić] Radovi XVII/3 (2014): 134-135.

${ }^{16}$ Hungarian National Archives, DL-DF 77442; Ernő Marosi, “Gyűrűs pecsét” [Ring seal] in Müvészet I. Lajos király korában, 1342-1382 [Art in the age of King Louis I, 13421382], ed. Ernő Marosi, Melinda Tóth and Lívia Varga (Budapest: MTA Művészettörténeti Kutató Csoport, 1982), 150.

17 One Polish historian also claims another short-lived daughter was born to the couple in 1365. Michael de Ferdinandy, "Ludwig I. von Ungarn (1342-1382)" in Louis the Great King of Hungary and Poland, ed. S. B. Vardy, Géza Grosschmid, Leslie S. Domonkos (Boulder, CO: East European Monographs, 1986), 32; Oscar Halecki and Tadeusz Gromada, Jadwiga of Anjou and the Rise of East-Central Europe (Boulder: Social Science Monographs, 1991), 49.

18 Geoffrey de la Tour-Landry and Anatole de Montaiglon, Le livre du chevalier de La Tour Landry, pour l'enseignement de ses filles (Paris: P. Jannet, 1854), 2.

${ }^{19}$ Sharon Jansen, Anne of France: lessons for my daughter (Woodbridge: D. S. Brewer, 2004), $13, \mathrm{n} 43$. 
murder in $1387 .{ }^{20}$ As consort, Elizabeth's activities were fairly marginal; it is only after she first becomes a mother and then a widow and regent that she gets access to greater power. But access to the power as regent was highly problematic as the court became factionalized, a rival from Naples invaded Hungary (Charles II, r. 1385-1386), culminating in Elizabeth's supporters murdering Charles II before she herself was strangled a year later. ${ }^{21}$

These two women differed not only in the circumstances by which they attained power but also in terms of their personalities and activities. As such, this essay aims to compare their reputation with their representation. There are a total of four pieces of what can be considered "public art" which are possible representations of Elizabeth of Poland and Elizabeth of Bosnia (two each). The elder queen Elizabeth is most likely represented in a keystone from the palace at Diósgyőr, a capital from the Church of Our Lady in Buda, while the younger Elizabeth is depicted in a stone carving from Mariazell as well as one from Zadar. The image of the two queens also appear on several important liturgical pieces, most notably a reliquary cross featuring Elizabeth of Poland and Charles I Robert from Spisska Nova Ves in Slovakia, ${ }^{22}$ an altarpiece by Lippo Vanni possibly featuring Elizabeth of Poland and her son Andrew, prince of Naples, ${ }^{23}$ and finally a magnificent silver reliquary sarcophagus Elizabeth of Bosnia had donated to the shrine of St. Simeon in Zadar (Fig. 2). ${ }^{24}$ Since these

20 Szilárd Süttő, Anjou-Magyarország Alkonya: Magyarország politikai története Nagy Lajostól Zsigmondig, az 1384-1387 évi belivszályok okmánytárával [The Twilight of Angevin Hungary: Hungary's political history from Louis the Great until Sigismund, 1384-1387 the years of internal strife in the charters] Vol. II (Szeged: Belvedere Meridionale, 2003), 2-414; Pál Engel, The Realm of St Stephen: History of Medieval Hungary 985-1526 (New York: I.B. Tauris, 2001), 198-199.

${ }^{21}$ Fine, The Late Medieval Balkans, 396-397. Pál Engel, The Realm of St. Stephen (New York: I.B. Tauris, 2001), 198; Bak, "Queens as Scapegoats in Medieval Hungary," 229231.

22 Sniezynska-Stolot, "Die Ikonographie der Königin Elisabeth,” 18-19; Szende, "Piast Erzsébet és udvara (1320-1380)" [Elizabeth Piast and her court (1320-1380)], 32.

23 Sniezynska-Stolot, "Die Ikonographie der Königin Elisabeth," 19-22; Nastasoiu, "Patterns of Devotion and Traces of Art during the Diplomatic Journey of Queen Elizabeth Piast to Italy in 1343-1344," 106-107.

${ }^{24}$ Ivo Petricioli, St. Simeon's Shrine in Zadar (Zagreb: Jugoslavenska akademija znanosti i umjetnosti, 1983), 12-22; Ana Munk, "The Queen and her Shrine: an art historical twist on historical evidence concerning the Hungarian Queen Elizabeth Kotromanić, donor 
images are discussed in greater detail elsewhere they shall only be mentioned here in the context of interpreting carved stone elements related to the queen. One caveat that is important to address is that many of these identifications were made decades ago using overly positivist thinking, i.e. a woman depicted wearing a crown must represent a certain historical queen.

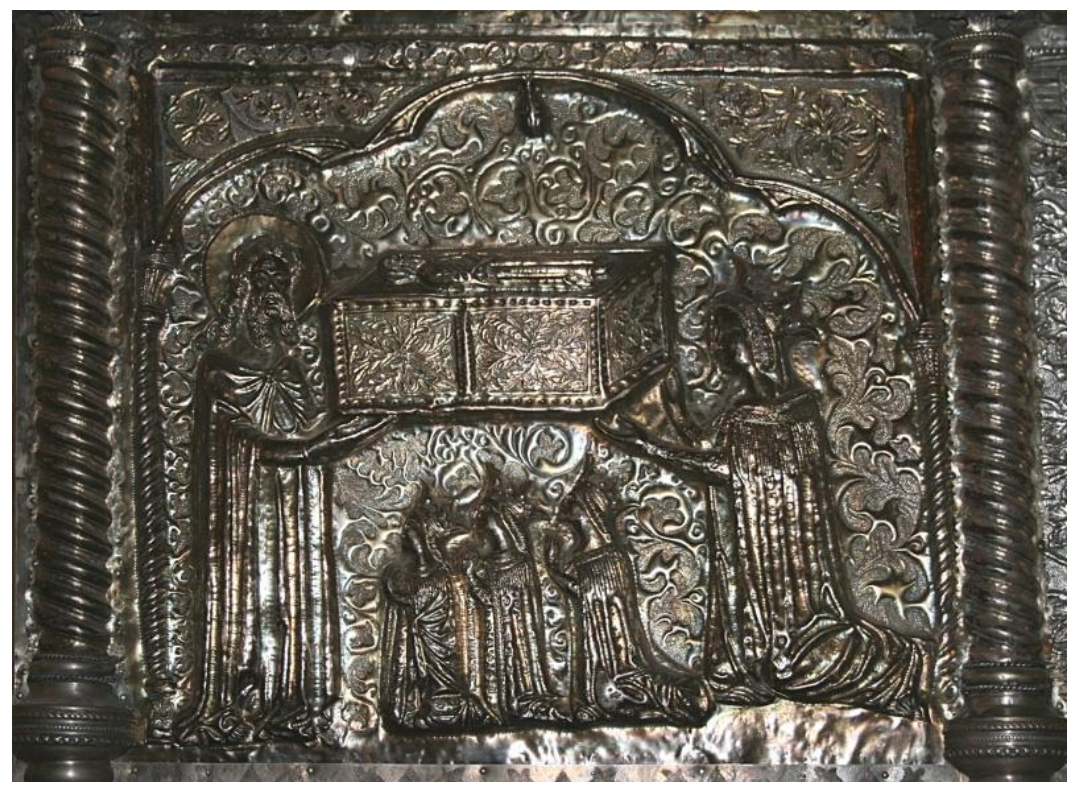

Fig. 2. Detail of the Sarcophagus of St. Simeon in Zadar featuring Elizabeth of Bosnia donating the reliquary along with her three daughters, Catherine, Mary, and Jadwiga Source: https://en.wikipedia.org/wiki/Chest_of_ Saint_Simeon\#/media/File:HAZU_77_17_lipnja_2008.jpg

The problem of circular reasoning has been tied to this issue, wherein a public image of a woman was tied to a historical queen either

of the Saint Simeon Shrine" Hortus Artium Medievalium 10 (2004): 253-262; Marina Vidas, "Elizabeth of Bosnia, Queen of Hungary, and the Tomb Shrine of St. Simeon in Zadar: Power and Relics in fourteenth-century Dalmatia" Studies in Iconography 29 (2008): 136-175; Marijana Kovačević, "The Omnipresent Death in the Iconography of Saint Simeon's Shrine in Zadar” IKON 4 (2011): 211-222. 
due to fashion or physiognomy and other similar pieces were likewise ascribed based on similar problematic evidence. For each of the images, this essay will try to discuss not only the context and audience, but also the reason why identifying the figures of most as Hungarian queens makes a certain degree of sense.

\section{A keystone from Diósgyőr and a capital from Buda representing Elizabeth of Poland}

The first example discussed here is a keystone made of grey andesite which would have originally come from the castle of Diósgyör, in eastern Hungary. Found in 1934 in the western wing of the castle, this keystone features a middle-aged woman with a plump face, a wide nose and grin, a low-cut frilled neckline and a frilled headdress in the style of kruselers (Fig. 3). Stylistically, it has been dated to the middle of the fourteenth century, perhaps around the $1360 \mathrm{~s}^{25}$ The realistic depiction of this woman has been compared to the Parler workshop; Peter and Wenzel Parler were master stonemasons responsible for not only work on the Cathedrals in Vienna and Prague, but also for the statues of the royal families ruling in those respective cities. ${ }^{26}$ Though the woman is not crowned (the top of her head is damaged, rendering it nigh impossible to tell if she was originally crowned), she has been identified either as Elizabeth of Poland or Elizabeth of Bosnia. Elizabeth of Poland wears a headdress like the woman depicted here in illuminations of her in the Hungarian Illuminated Chronicle, while Elizabeth of Bosnia is wearing a similar headdress in the sarcophagus of St. Simeon. ${ }^{27}$ The main reason why this keystone is most likely that of the elder Queen Elizabeth, is that Diósgyôr, a royal property since 1323, was her

25 Ilona Czeglédy, "Zárókő női fejjel” [Keystone with the head of a woman] in Müvészet I. Lajos király korában, 1342-1382 [Art in the age of King Louis I, 1342-1382], ed. Ernő Marosi, Melinda Tóth and Lívia Varga (Budapest: MTA Műészettörténeti Kutató Csoport, 1982), 240-241.

${ }^{26}$ László Gerevich, The Art of Buda and Pest in the Middle Ages (Budapest: Akadémiai Kiadó, 1971), 71; Robert Odell Bork, The Geometry of Creation: Architectural Drawing and the Dynamics of Gothic design (Farnham: Ashgate, 2011), 231.

27 Czeglédy, "Zárókő női fejjel", 241. Annamária Kovács, "Courtly Costumes in Fourteenth-Century Hungary" in "Quasi Liber et Pictura": Studies in Honour of András Kubinyi on his Seventieth Birthday, ed. Gyöngyi Kovács (Budapest: ELTE Institute of Archaeological Sciences, 2004), 307; Ivo Petriolici, St. Simeon's Shrine in Zadar (Zagreb: Jugoslavenska akademija znanosti i umjetnosti, 1983), 29-30. 
property from 1340, specifically referenced as the queen's castle. ${ }^{28}$ Though the earliest known evidence for either Elizabeth staying at the castle comes from a charter of the elder queen dated from 1369, ${ }^{29}$ it seems that during the 1370 s it was a site frequently visited by both queens..$^{30}$ In the mid-fourteenth century, the castle was re-built in the style of a French donjon with a central courtyard surrounded by four towers.

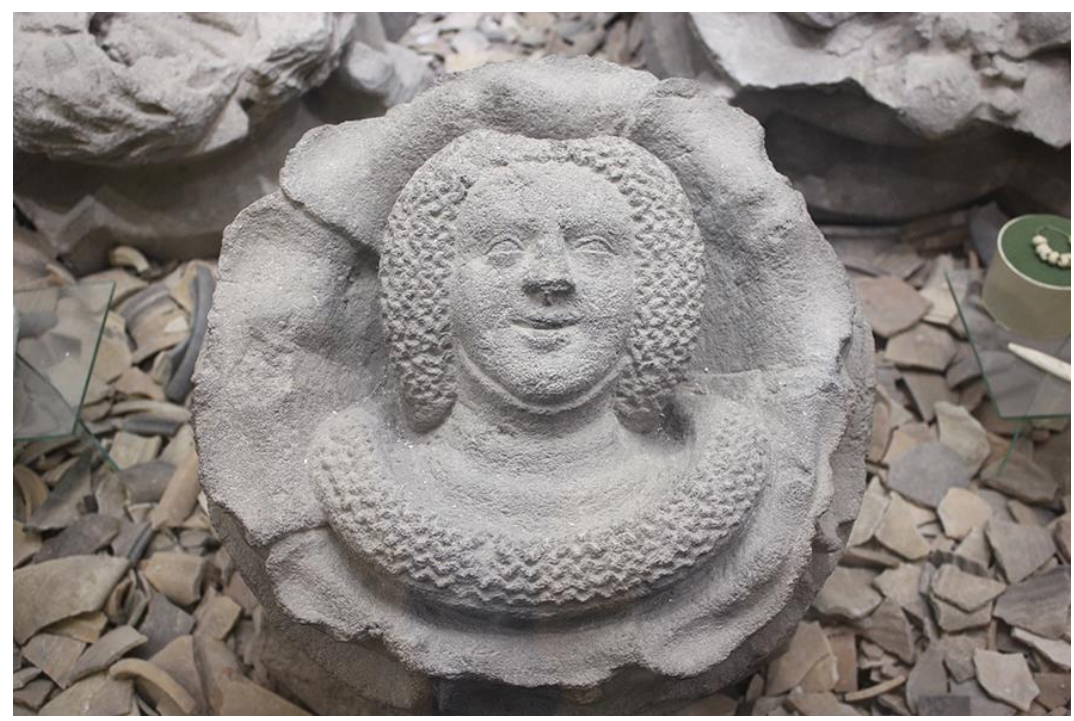

Fig. 3. Keystone featuring Elizabeth of Poland from the castle of Diósgyőr (Inventory Number 69.4.1)

Courtesy of the Diósgyőri Vár

While the eastern and southern wings of this castle would have consisted of chapels and royal residences on the upper floors, the

${ }^{28}$ Czeglédy, The Castle of Diósgyör, 11; László Szende, "Les châteaux de reines comme résidence dans la Hongrie des Anjoux" in Archaeologia dei castelli nell'Europa angioina (secoli XIII-XV), ed. Paolo Peduto et al. (Borgo San Lorenzo [Florence]: All'Insegna del Gigliio, 2011), 164.

${ }^{29}$ In this charter, Elizabeth of Poland uses the seal of Charles I Robert, her deceased husband. Hungarian National Archives DL-DF 52140.

${ }^{30}$ Hungarian National Archives DL-DF 77442, 219632, 6140, 6330, 87522, 89487. 
northern wing had a great hall ${ }^{31}$ and the western wing would have most likely been a public space as well. The keystone likely depicting Elizabeth of Poland would have originally been part of a cross-vaulted ceiling on the upper storey of the western wing and other keystones such as a grotesque and a dragon with a nest of eggs would have appeared alongside the queen; Czéglegy hypothesizes that this room would have been a dining hall. ${ }^{32}$ While the renovations that took place at Diósgyőr are usually attributed to Louis I, it is possible that they could be the handiwork of Elizabeth, the owner of the palace, especially considering her aforementioned construction projects related to monasteries and the palace at Óbuda. With this in mind, the keystone of the queen would have been visible in a very public part of the castle where the court and many guests would have seen it.

Another stone carving believed to be Elizabeth of Poland would have come from a capital at the St. Mary Gate on the south side of the Church of Our Lady in Buda (known as the Matthias Church today). Plaster casts made of these figures originally identified the crowned man with long hair and a beard as Louis I and the figure of the crowned woman as Elizabeth of Poland. While the king was identified as Louis due to his similarity with the figure at Mariazell (see below), the queen was identified as his mother mostly on the basis of the crown and her veil (Fig. 4). ${ }^{33}$ Her wide nose and mouth also bear a strong resemblance to the figure at Diósgyőr. This capital has been dated to around 1370-1380, near the end of the queen's life (and that of her son's). ${ }^{34}$ Within the vicinity of modern-day Budapest, Elizabeth of Poland was instrumental in funding, re-building, or renovating at least ten churches and monasteries. ${ }^{35}$ While it is unknown if the queen

31 Gergely Buzás, "The Functional Reconstruction of the Visegrád Royal Palace" in The Medieval Royal Palace at Visegrád, ed. Gergely Buzás and József Laszlovszky (Budapest: Archaeolingua Press, 2013), 169; Szende, "Les châteaux de reines," 164.

32 Ilona Czeglédy, The Castle of Diósgyör (Budapest: Corvina Press, 1971), 10-11, 31.

33 József Csemegi, A budavári fötemplom középkori épitéstörténete [The medieval building history of the main church of Buda Castle] (Budapest: Képzőmunvészeti Alap Kiadóvállalata, 1955), 96-97.

34 Csemegi, A budavári fótemplom, 97.

35 These were the Franciscan convent of St. Clara on Margaret Island in the Danube River, the Premonstratensian monastery of the Archangel Michael also on Margaret Island, the Dominican nunnery on Margaret Island as well, the Poor Clares cloister in Óbuda, the collegiate churches of Our Lady and St. Peter in Óbuda, the Augustinian monastery of St. Stephen in Buda, the church of the Carmelites in Buda, the chapel of 
played any part in any construction at the Church of Our Lady in Buda, considering her patronage of other churches, it is entirely possible that her image could reflect her interest in the building. The St. Mary Gate of the Church of Our Lady in Buda would have been visible to those entering the church that way; while the image of her would not have specifically targeted members of the court as the keystone in Diósgyör, the capital in Buda would have had a wider audience, especially since it was on the outside of the church.

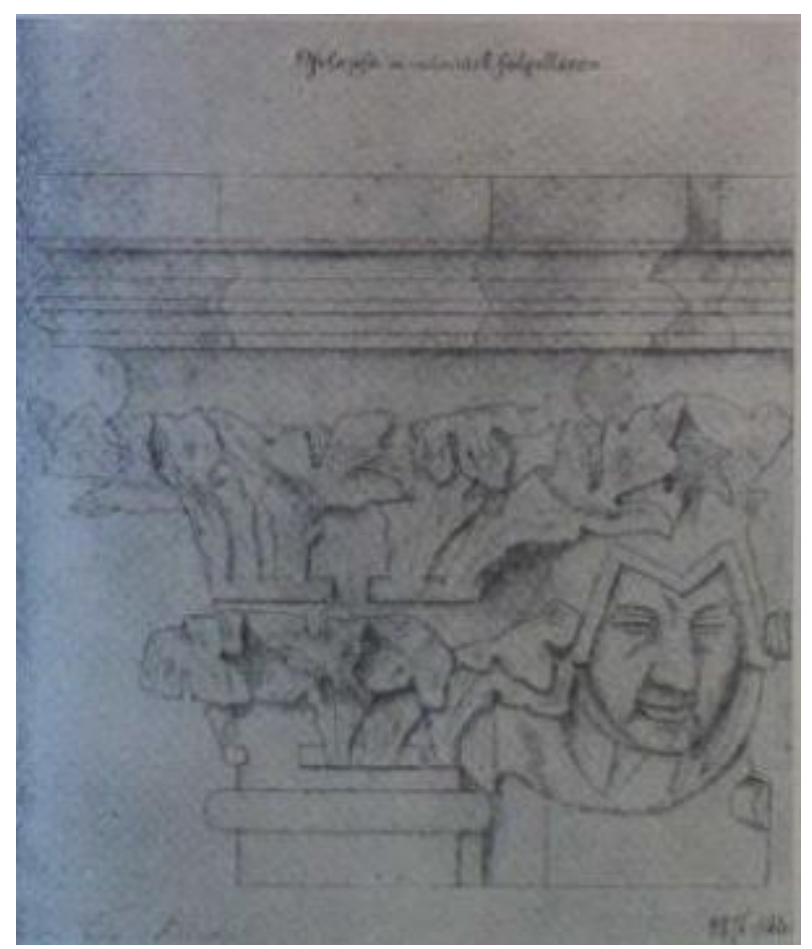

Fig. 4. Drawing of the capital from St. Mary Gate at the Church of Our Lady in Buda featuring Elizabeth of Poland Drawing by Josef Keintzel, 1876. From József Csemegi, A budavári fötemplom középkori építéstörténete (1955) (photo: the author)

St. Martin in Buda and the Chapel of Our Lady in Buda Castle. Éva Sniezynska-Stolot, "Queen Elizabeth as a patron of Architecture" Acta Historiae Artium 20 (1974): 13-28. 


\section{Stone carvings featuring Elizabeth of Bosnia from Mariazell and Zadar}

While Elizabeth of Poland's sculptural figures are in the heart of royal centres during the Angevin rule in Hungary, sculptures depicting Elizabeth of Bosnia are either on the fringe or outside of the kingdom's borders. A relief showing a bearded king and a youthful queen from the shrine at Mariazell, has long been linked with Louis I of Hungary and Elizabeth of Bosnia. After Louis I had a vision of the Virgin Mary encouraging him in battle in 1363, he built a Gothic church around the shrine at Mariazell, with additional construction funded by the king taking place in 1380 and 1400.36 While the Gnadenkapelle ("Grace Chapel") was re-built centuries later in Baroque style, several medieval pieces were incorporated; in particular, a Gothic canopy which features a red marble tableau of the king and queen. While the king appears to be older and bearded, the queen is much more youthful and her features are much more idealized (Fig. 5). The pair wears similar crowns, draped clothing and the field behind them is decorated with grapes and vine leaves. There are many possibilities for their original placement within the shrine church, but it seems most likely that the king would have been part of the rood screen separating the nave from the choir. ${ }^{37}$ The carving of the queen's mouth has been shown to be very similar to the carving the Parler workshop did of Anna of Schweidnitz, wife of Charles IV of Bohemia, in Prague; thus the conclusion is that (like the statue of the queen from Diósgyőr), it is likely that the workshop of Peter Parler also made these portraits of the king and queen. ${ }^{38}$ That being said, the dating of this royal pair is problematic; since the rood altar was consecrated in 1369, it was originally hypothesized that the sculpture would have been made around that time. However, a combination of stylistic comparison as well as the construction of three new altars in 1383 caused Marosi to argue for a later date of 1383, suggesting that Louis I was not alive and

\footnotetext{
${ }^{36}$ József Szamosi, "König Ludwig der Grosse: Bauten und Denkmäler in Mariazell” in Louis the Great: King of Hungary and Poland, ed. S. B. Vardy et al. (Boulder: East European Monographs, 1986), 291-294.

${ }^{37}$ Ernő Marosi, "Mariazell und die Kunst Ungarns im Mittelalter" in Ungarn in Mariazell - Mariazell in Ungarn: Geschichte und Erinnerung, ed. Péter Farbaky, Szabolcs Serfőző (Budapest: 2004), 31.

38 Szamosi, “König Ludwig der Grosse: Bauten und Denkmäler in Mariazell,” 303-304.
} 
probably had no involvement in creating this relief. ${ }^{39}$ If this is the case, it raises the possibility whether or not Elizabeth commissioned this as a way of completing the charitable project of her husband. Doing so would also serve a broader diplomatic purpose. Elizabeth did not look favourably on the marital alliances her husband had made for her daughters, trying to dissolve marital alliances between the Habsburgs and the Luxemburgs in favour of a French match. After the Polish noble broke off the engagement of her daughter Jadwiga (Queen of Poland r. 1384-1399) with Wilhelm of Austria (d. 1406), Wilhelm arrived at the Hungarian court in 1385 to press his rights as bridegroom. ${ }^{40}$ The queen was in no position to anger such a powerful ally (especially so close to Charles of Durazzo who invaded and deposed her daughter Maria later that year), and erecting the images of her and her husband as part of a rood screen at a renowned shrine in Austria not only would have enhanced her image abroad, but it also could have been seen as a gesture of mollifying the spurned Habsburgs.

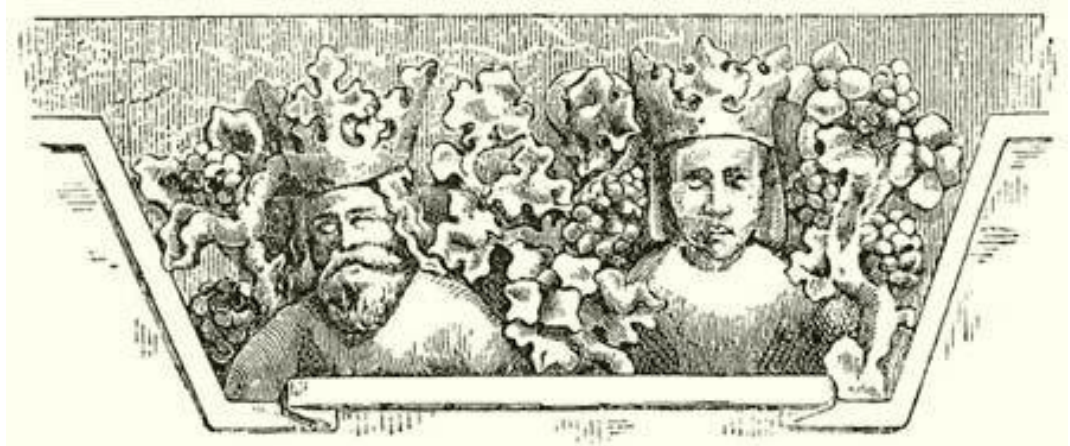

Fig. 5. Possible former rood screen featuring Louis I of Hungary and Elizabeth of Bosnia

Drawing from Márki, Sándor. Mária Magyarország királynéja 1370-1395.

Budapest: A Magyar történelmi társulat kiadása, 1885, 60.

Elizabeth of Bosnia is also featured in another public monument associated with the Church of St. Simeon in Zadar. There is a limestone relief featuring St. Simeon in the centre, a kneeling queen to the

\footnotetext{
39 Ibid.; Marosi, "Mariazell und die Kunst Ungarns im Mittelalter," 31-32.

40 Oscar Halecki and Tadeusz Gromada, Jadwiga of Anjou and the Rise of East Central Europe (New York: Columbia University Press, 1991), 100-101, 116, 131.
} 
viewer's right, and to the viewer's left two angels stand above a blank escutcheon with a helmet resting on top of it (Fig. 6). The queen is wearing a crown with a veil covering her hair and she is grasping the tie to her cloak. The presence of the blank coat-of-arms, the crown, and the Queen's history of association with the site all indicate that it was most likely depicting Elizabeth of Bosnia's devotion to St. Simeon. ${ }^{41}$ Based on similar sculpture from the area, it has been proposed that the artist who made this relief featuring the queen was Pavao of Sulmona, a sculptor active from 1386 to 1405 who also made the tomb of Archbishop Nikola Matafar in Zadar. ${ }^{42}$ His period of activity raises the question of Elizabeth's involvement in this sculpture. Elizabeth was strangled in front of her daughter while they were imprisoned in Novigrad Castle in January 1387. If Elizabeth commissioned this relief (as she did the sarcophagus), then this relief would have been one of Pavao's earliest known works. However, if the monument was made after the queen's death, when Pavao of Sulmona was more active as a sculptor, the person most likely responsible for commissioning it would have been her daughter, Queen Mary of Hungary (r. 1382-1395). After Mary was restored to the Hungarian throne under a period of joint rule with her husband Sigismund (r. 1387-1437), Mary would have moved the body of her mother Elizabeth from its place of burial at the Church of St. Chrysogonus in Zadar and buried her in the royal basilica at Székesfehérvár under a life-size white marble effigy. ${ }^{43}$ Since Elizabeth of Bosnia's body had originally been laid to rest in Zadar before being transferred to the traditional burial place of the Hungarian royal family, it seems very likely that Mary would have erected this after her mother's death. This relief shows not only the queen's devotion to St. Simeon,

${ }^{41}$ Ivo Petricioli, St. Simeon's Shrine in Zadar (Zagreb: Jugoslavenska akademija znanosti i umjetnosti, 1983), 6.

${ }^{42}$ Ivo Petricioli, "Još o Pavlo iz Sulmone - graditelju pročelja crkve u Starom Pagu" [Pavao of Sulmona - builder of the façade of the church in Old Pag] Ars Adriatica 3 (2013): 111-120.

43 Ildikó Hankó, A magyar királysírok sorsa: Géza fejedelemtöl Szapolyai Jánosig [The fate of the royal Hungarian graves: from Prince Géza to John Szapolyai] (Budapest: Magyar Ház, 1987), 137; Kinga Éry, Antónia Marcsik, János Nemeskéri, Ferenc Szalai, "Az épített sírok csontvázleletei (I. csoport)," [The skeletons in the built graves] in $A$ Székesfehérvári királyi bazilika embertani leletei 1848-2002 [Anthropological finds from the royal basilica of Székesfehérvár, 1848-2002], ed. Kinga Éry (Budapest: Balassi, 2008), 100. 
but its representation of the crown and coat-of-arms (albeit blank) would have originally shown her rank and status. Its large size (217 by $118 \mathrm{~cm})$ and evident wear indicates that this relief spent a significant amount of time facing the elements, indicating that it was a very public monument associated with the church.

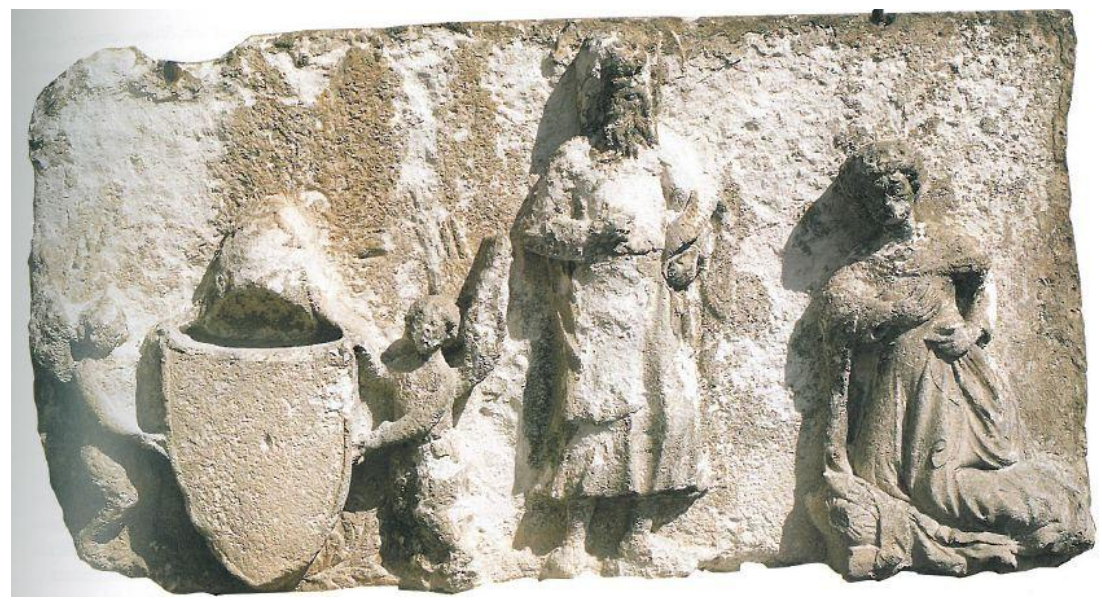

Fig. 6. Relief of Elizabeth of Bosnia kneeling before St. Simeon

Courtesy of the National Museum Zadar, Inventory Number MGZ-356

\section{Conclusions}

Comparing the iconographic programmes of these two queens reveals an intriguing dynamic in terms of their own self-representation. Elizabeth of Poland, who seems only ambiguous and controversial in unfriendly chronicles, appears in "public" monuments as a matronly older woman with a wide nose. Considering that most sculpture emphasizes an idealized version of the person it is supposed to represent, the decision for the queen to appear in a more realistic manner is a bold one. In French illuminations and altarpieces, the consort is usually depicted in an idealized, much more static way; she is identifiable through gestures, heraldry, and dress and less attention is paid to her likeness than to showing the viewer her rank. ${ }^{44}$ The context

44 Stephen Perkinson, The likeness of the king: a prehistory of portraiture in late medieval France (Chicago: University of Chicago Press, 2009), 208, 263, 268. 
for the keystone from Diósgyőr is particularly interesting due to its association with entertaining the court. This is in marked contrast to her daughter-in-law, Elizabeth of Bosnia. The younger queen, whose public images seem to only appear during her widowhood and regency (and even possibly after her death) depict this queen in an idealized, youthful manner. The serene countenance on the sculptures of her from Mariazell and Zadar do not depict a woman caught up in a diplomatic game of chess which would cost her life, but rather as a devoted, pious woman active in supporting the church. The different representations of the two women could simply be the result of pragmatic concerns; the sculptures of Elizabeth of Poland date from a time when she would have been in her sixties and seventies while Elizabeth of Bosnia would have been around 40-45 (or dead) when the two stone sculptures were made of her. That being said, it seems much more likely to refer to the relative strength of their positions as the main reason for the difference in appearance. Even though the elder Elizabeth's regency in Poland was unpopular, she still enjoyed a strong position in Hungary, was incredibly wealthy, and was regarded as a strong supporter of the Church. When compared to the regency of her daughter-in-law who faced multiple enemies at home and abroad, Elizabeth of Bosnia needed to project an image of strength and security. In both cases, the queens were meant to be recognized as queens; the message, however, was different. In Elizabeth of Bosnia's weak position as regent, she needed to be recognized abroad as having control over internal affairs, regardless of whether or not that was actually the case. For Elizabeth of Poland, whose primary audience would have been members of the court and the citizens of Buda, it was enough for her to simply be recognized.

\section{Bibliography}

\section{Primary Sources}

Dercsényi, Dezső, ed. The Hungarian Illuminated Chronicle. Budapest: Corvina Kiadó, 1969.

Długosz, Jan and Maurice Michael, ed. The Annals of Jan Dtugos: Chichester: IM Publications, 1997. 
Geoffrey de la Tour-Landry and Anatole de Montaiglon. Le livre du chevalier de La Tour Landry, pour l'enseignement de ses filles. Paris: P. Jannet, 1854.

Süttő, Szilárd. Anjou-Magyarország Alkonya: Magyarország politikai története Nagy Lajostól Zsigmondig, az 1384-1387 évi belivszályok okmánytárával [The Twilight of Angevin Hungary: Hungary's political history from Louis the Great until Sigismund, 1384-1387 the years of internal strife in the charters]. Vol. I-II. Szeged: Belvedere Meridionale, 2003.

\section{Secondary Sources}

Altmann, Julianna. "Neueste Forschungen der Burg der Königin in Óbuda." Acta Archaeologica Academiae Scientiarum Hungariae 34 (1982): 249-267.

Altman, Julianna. “Óbuda.” In Medium Regni: Medieval Hungarian Royal Seats, ed..Julianna Atlmann et al, 89-109. Budapest: Nap Kiadó, 1999.

Bak, János M. “Queens as Scapegoats in Medieval Hungary.” In Queens and queenship in medieval Europe ed. Anne J. Duggan, 223-233.

Woodbridge: Boydell Press, 2002.

Bertalan, Herta. "Óbudai Klarissza Kolostor" [The Obuda Poor Claires Cloister]. Budapest Régiségei 27 (1976): 269-278.

Bertalan, Herta. "Das Klarissenkloster von Óbuda aus dem 14. Jahrhundert." Acta Archaeologica Academiae Scientiarum Hungaricae 34 (1982): 151-176.

Bork, Robert Odell. The Geometry of Creation: Architectural Drawing and the Dynamics of Gothic design. Farnham: Ashgate, 2011.

Buzás, Gergely. "The Functional Reconstruction of the Visegrád Royal

Palace.”I In The Medieval Royal Palace at Visegrád, ed..Gergely

Buzás and József Laszlovszky, 143-196. Budapest:

Archaeolingua Press, 2013.

Csemegi, József. A budavári fótemplom középkori épitéstörténete [The medieval building history of the main church of Buda Castle]. Budapest: Képzőmúvészeti Alap Kiadóvállalata, 1955.

Czeglédy, Ilona. The Castle of Diósgyör. Budapest: Corvina Press, 1971. "Zárókő nói fejjel" [Keystone with the head of a woman]. In Müvészet I. Lajos király korában 1342-1382 [Art in the age of King Louis I, 1342-1382], ed. Ernő Marosi, Melinda Tóth and Lívia 
Varga, 240-241. Budapest: MTA Műészettörténeti Kutató Csoport, 1982.

Dautović, Dženan. "Bosansko-ugarski odnosi kroz prizmu braka Ludovika I Velikog i Elizabete kćerke Stjepana II Kotromanića” [Relations between Bosnia and Hungary through the prism of the marriage between Louis the Great and Elizabeth, the Daughter of Stjepan II Kotromanić].” Radovi XVII/3 (2014): 141-157. Engel, Pál. The Realm of St Stephen: History of Medieval Hungary 985-1526. New York: I.B. Tauris, 2001.

Éry, Kinga, Antónia Marcsik, János Nemeskériand Ferenc Szalai. “Az épített sírok csontvázleletei (I. csoport)" [The skeletons of the built graves]. In A Székesfehérvári királyi bazilika embertani leletei 1848-2002 [Anthropological finds from the royal basilica of Székesfehérvár, 1848-2002], ed. Kinga Éry, 37-118. Budapest: Balassi Kiadó, 2008.

Ferdinandy, Michael de. "Ludwig I. von Ungarn (1342-1382)." In Louis the Great: King of Hungary and Poland, ed. S. B. Vardy et al., 3-48. Boulder: East European Monographs, 1986.

Fine, John. The Late Medieval Balkans. Ann Arbor: University of Michigan Press, 1994.

Gárdonyi-Csapodi, Klára. "Description and Interpretation of the Illustrations in the Illuminated Chronicle." In The Hungarian Illuminated Chronicle: Chronica de Gestis Hungarorum, ed. Dezső Dercsényi, 70-85. Budapest: Corvina Press, 1969.

Halecki, Oscar and Tadeusz Gromada. Jadwiga of Anjou and the Rise of East Central Europe. New York: Columbia University Press, 1991. Hankó, Ildikó. A magyar királysirok sorsa: Géza fejedelemtöl Szapolyai Jánosig [The fate of the royal Hungarian graves: from Prince Géza to John Szapolyai]. Budapest: Magyar Ház, 1987.

Havasi, Krisztina. “A király új palotája. Megjegyzések a kora 13. századi óbudai rezidencia múvészettörténeti helyéhez" [A new palace for the king. remarks on the place in art history of the early $13^{\text {th }}$-century royal residence at Óbuda]. In In medio regni Hungariae. Régészeti, Müvészettörténeti és történeti kutatások 'az ország közepén': Archaeological, Art Historical, and Historical Researches 'in the Middle of the Kingdom,' ed. Elek Benkő and Krisztina Orosz. Budapest: Magyar Tudományos Akadémia, 2015.

Jansen, Sharon. Anne of France: lessons for my daughter. Woodbridge: D. S. Brewer, 2004. 
Kovačević, Marijana. "The Omnipresent Death in the Iconography of Saint Simeon's Shrine in Zadar." IKON 4 (2011): 211-222.

Kovács, Annamária. "Courtly Costumes in Fourteenth-Century Hungary." In "Quasi Liber et Pictura": Studies in Honour of András Kubinyi on his Seventieth Birthday, ed. Gyöngyi Kovács, 301-310. Budapest: ELTE Institute of Archaeological Sciences, 2004. Kristó, Gyula. "Károly Róbert családja” [The Family of Charles Robert]. Aetas 20:4 (2005): 14-28.

Lillich, Meredith Parsons. The Queen of Sicily and Gothic Stained Glass in Mussy and Tonnerre. Philadelphia: American Philosophical Society, 1998.

Marosi, Ernő. “A 14. századi Magyarország udvari múvészettörténetírásban." [The fourteenth century Hungarian court in the art historical literature]. In Müvészet I. Lajos király korában 1342-1382, ed. Ernő Marosi, Melinda Tóth and Lívia Varga, 51-77. Budapest: MTA Múvészettörténeti Kutató Csoport, 1982. . "Gyürüs pecsét" [Ring seal]. In Müvészet I. Lajos király korában, 1342-1382 [Art in the age of King Louis I, 1342-1382], ed. Ernő Marosi, Melinda Tóth and Lívia Varga, 150. Budapest: MTA Mûvészettörténeti Kutató Csoport, 1982.

. "Mariazell und die Kunst Ungarns im Mittelalter." In Ungarn in Mariazell-Mariazell in Ungarn: Geschichte und Erinnerung, ed. Péter Farbaky, Szabolcs Serfőző, 28-38. Budapest: 2004.

McEntee, Brian. "The Burial Site Selection of a Hungarian Queen: Elizabeth, Queen of Hungary (1320-1380), and the Óbuda Clares' Church.” Annual of Medieval Studies at CEU 12 (2006): 69-82. . "Queen Elizabeth of Hungary (1320-1380) and Óbuda: Patronage, Personality and Place." In La diplomatie des États Angevins au XIIIe et XIVe siècles, ed. Zoltán Kordé and István Petrovics, 209218. Rome and Szeged, 2010.

Munk, Ana. "The Queen and her Shrine: an art historical twist on historical evidence concerning the Hungarian Queen Elizabeth Kotromanić, donor of the Saint Simeon Shrine." Hortus Artium Medievalium 10 (2004): 253-262.

Nastasoiu, Dragoş Gheorge. "Patterns of Devotion and Traces of Art during the Diplomatic Journey of Queen Elizabeth Piast to Italy in 1343-1344." In Convivium: Exchanges and Interactions in the Arts of 
Medieval Europe, Byzantium, and the Mediterranean, ed. Michele Bacci and Ivan Foletti, 98-111. Turnhout: Brepols, 2015.

. "Patterns of Devotion and Traces of Art. The Pilgrimage of

Queen Elizabeth Piast to Marburg, Cologne, and Aachen in 1357."

Umèní LXIV (2016): 29-43.

Nolan, Kathleen. Queens in Stone and Silver: the creation of a visual imagery of queenship in Capetian France. New York: Palgrave Macmillan, 2009.

Perkinson, Stephen. The likeness of the king: a prehistory of portraiture in late medieval France. Chicago: University of Chicago Press, 2009.

Petricioli, Ivo. St. Simeon's Shrine in Zadar. Zagreb: Jugoslavenska akademija znanosti i umjetnosti, 1983.

. "Još o Pavlo iz Sulmone - graditelju pročelja crkve u Starom

Pagu." [Pavao of Sulmona - builder of the façade of the church in Old Pag]. Ars Adriatica 3 (2013): 111-122.

Romhányi, Beatrix. Kolostorok és társaskáptalanok a középkori

Magyarországon: katalógus [Monasteries and the collegiate chapters of medieval Hungary: a catalog]. Budapest: Pytheas, 2000.

Sághy, Marianne. "Dévotions diplomatiques: Le pèlerinage de la reinemère Élisabeth Piast à Rome." In La Diplomatie des États Angevins aux XIIIe et XIVe siècle, ed. Zoltán Kordé and István Petrovics, 219-224. Rome and Szeged, 2010.

Sniezynska-Stolot, Eva. "Die Ikonographie der Königin Elisabeth." Acta Historiae Artium 17 (1971): 17-29.

. "Queen Elizabeth as Patron of Architecture." Acta Historiae Artium 20 (1974): 13-36.

Steane, John. The archaeology of the medieval English Monarchy. London \& New York: Routledge, 1999.

Szamosi, József. "König Ludwig der Grosse: Bauten und Denkmäler in Mariazell." In Louis the Great: King of Hungary and Poland, ed. S. B. Vardy et al., 285-324. Boulder: East European Monographs, 1986. Szende, László. "Mitherrscherin oder einfache Königinmutter Elisabeth von Łokietek in Ungarn (1320-1380).” Majestas 13 (2005): 47-63. . Piast Erssébet és udvara (1320-1380) [Elizabeth Piast and her court, 1320-1380]. PhD diss.: ELTE, 2007.

. "Les châteaux de reines comme résidence dans la Hongrie des Anjoux." In Archaeologia dei castelli nell'Europa angioina (secoli XIII-XV), ed. Paolo Peduto et al., 158-165. Borgo San Lorenzo [Florence]: All'Insegna del Gigliio, 2011. 
Vidas, Marina. "Elizabeth of Bosnia, Queen of Hungary, and the Tomb Shrine of St. Simeon in Zadar: Power and Relics in fourteenthcentury Dalmatia." Studies in Iconography 29 (2008): 136-175. 